\title{
Ventilation at Supra-Optimal Temperature Leading High Relative Humidity Controls Powdery Mildew, Silverleaf Whitefly, Mite and Inhibits the Flowering of Korean Melon in a Greenhouse Cultivation
}

\author{
Tae Cheol Seo ${ }^{1 *}$, Jin Hyun Kim², Seung Yu Kim¹, Myeong Whan Cho², Man Kwon Choi \\ Hee Ryong Ryu ${ }^{4}$, Hyun Ho Shin ${ }^{3}$, and Choung Keun Lee ${ }^{1}$ \\ ${ }^{1}$ Senior Researcher, Protected Horticulture Research Institute, NIHHS, RDA, Haman 52054, Korea \\ ${ }^{2}$ Researcher, Protected Horticulture Research Institute, NIHHS, RDA, Haman 52054, Korea \\ ${ }^{3}$ Postdoctorial Researcher, Protected Horticulture Research Institute, NIHHS, RDA, Haman 52054, Korea \\ ${ }^{4}$ Researcher, R\&D Performance Evaluation \&Management Division, Research Policy Bureau, RDA, Jeonju 54875, Korea
}

\begin{abstract}
This study was conducted to investigate the effect of ventilation at high temperature on the control of powdery mildew, silverleaf whitefly two-spotted spider mite occurred at Korean melon cultivation greenhouse, and on leaf rolling and flowering of the plant in summer season. 'Alchanggul' grafted onto 'Hidden Power' rootstock was planted on soil bed with the distance of $40 \mathrm{~cm}$. Three ventilation temperatures of $45^{\circ} \mathrm{C}, 40^{\circ} \mathrm{C}$, and $35^{\circ} \mathrm{C}$ as set points were compared. Ventilation treatment was done by control of side window operation from 18th June to 13th July when silverleaf whitefly, mite, and powdery mildew were occurred in all greenhouses. The temperature inside greenhouse was increased up to the set temperature point on sunny days and maintained for about 9 hours with high relative humidity at $45^{\circ} \mathrm{C}$ condition. The differences of day maximum air temperature and day minimum $\mathrm{RH}$ were the highest at $45^{\circ} \mathrm{C}$ treatment. After 11 days of treatments, the damage by powdery mildew and two-spotted spider mite was almost recovered at $45^{\circ} \mathrm{C}$ treatment but not at 40 and $35^{\circ} \mathrm{C}$. The population of silverleaf whitefly and two-spotted spider mite were significantly decreased at $45^{\circ} \mathrm{C}$ treatment at 14 days after treatment, while powdery mildew symptom was not significantly decreased. Leaf rolling was observed at high temperature but not severe at $45^{\circ} \mathrm{C}$ treatment. After 26 days of treatments, female flowers did not bloom at all at $45^{\circ} \mathrm{C}$ treatment, and the number of male flowers was 1.2 among 15 nodes of newly grown shoots. As the result, it indicates that ventilation at the high temperature of $45^{\circ} \mathrm{C}$ for about 2 to 3 weeks can be an applicable method to control above mentioned pests and disease, and to recover the vegetative growth of Korean melon by reducing flowering of the plant.
\end{abstract}

Additional key words : Bemisia tabaci, leaf rolling, microclimate, Podosphaera xanthii, Tetranychus ulticae

\section{Introduction}

Korean melon (Cucumis melo L.) cultivation has been done for 8 to 9 months from early winter to late summer in Seongju county in Gyeongbuk province in Korea. Therefore, plants experience various climate conditions and encounter various pests and diseases during the cultivation period. For long-term stable production of Korean melon, the balance of vegetative growth and reproductive growth with healthy and sound plant body without damage by pests and diseases is very necessary.

Korean melon withers suddenly when the number of fruits is so many in compared to the number of leaves having a role

*Corresponding author: tcseo2@korea.kr

Received November 4, 2021; Revised January 18, 2022;

Accepted January 19, 2022 of photosynthesis, especially at warm and hot season (RDA, 2018). Thus, cutting down the fruit roads is recommended to inhibit sudden withering. However, the artificial control of the number of fruit set is very difficult and laborious because the fruit set of Korean melon is mostly done by pollinating bee randomly.

Generally, chemical control is being applied to protect plants from pest and diseases. Powdery mildew (Podosphaera xanthii) (PM) occurring in the greenhouse cultivation of Korean melon is an intractable disease to be hardly controlled by chemicals (Yeon et al., 2020). Silverleaf whitefly (Bemisia tabaci) (SW) is also one of the several species of whitefly that are currently a wide spread pest (Wikipedia, 2021b). In addition, two-spotted spider mite (Tetranychus ulticae Koch) also occurs so often in Korean melon cultivation field (RDA, 2018). These kinds of disease and pests occur 
Tae Cheol Seo, Jin Hyun Kim, Seung Yu Kim, Myeong Whan Cho, Man Kwon Choi, Hee Ryong Ryu, Hyun Ho Shin, and Choung Keun Lee

often simultaneously during the summer season. Moreover, chemical control is very limited at this time. In this situation, environmental control can be applied as an alternative way (Yeon et al., 2020). For instance, the exposal of high temperature by 46 to $49^{\circ} \mathrm{C}$ for 30 minutes was very effective and satisfied method to control powdery mildew as an environmental control by closing side window on the sunny day (Choi, 2013). However, there are few reports on the effect of high temperature/humidity on the silverleaf whitefly and mites control in laboratory level. The effect of heat shock on survival and reproduction of whitefly species (Cui et al., 2008) and the effect of steam at $48^{\circ} \mathrm{C}$ on mite using strawberry leaf discs (Renkema et al., 2020) are reported.

Meanwhile, supra-optimal high temperature functions as abiotic stresses on plant (Fahad et al., 2017) which affect growth and flowering (McClung et al., 2016; Vu et al., 2020), leaf morphology (Leigh et al., 2017; Park et al., 2019). Leaf rolling was reviewed as one of responses to abiotic stress such as water deficit, high and low temperature, solar radiation, and other factors (Kadioglu et al., 2012). We can observe leaf rolling so often in Korean melon cultivation greenhouse in spring and summer season, which is thought to be a symptom resulted from heat and water stress.

Therefore, the aim of this study is to investigate the effect of ventilation at supra-optimal temperature on the microclimate change inside greenhouse and its control effect of powdery mildew, silverleaf whitefly, mites, leaf rolling, and flowering of Korean melon in greenhouse cultivation in summer season.

\section{Materials and Method}

This experiment was conducted in 15 single roof plastic greenhouses (Fig. 1) at Protected Horticulture Research Institute under National Institute of Horticultural and Herbal Science, located at Haman county, Gyeongnam province, Korea. The greenhouse was structured by iron pipe with $1.3 \mathrm{~m}$ eve height and $2.5 \mathrm{~m}$ ridge height, and covered with $0.15 \mathrm{~mm}$ thick plastic film having the surface area of $40 \mathrm{~m}^{2}$ with $5 \mathrm{~m}$ width and $8 \mathrm{~m}$ length, which was equipped with rolling type side window operated by the temperature sensor located at the center of greenhouse on $1.5 \mathrm{~m}$ height. Insect screen was also equipped on both side of side window. Canopy climate data was collected instantaneously by monitoring system and stored at computer by hour average. Solar radiation, air temperature, relative humidity (RH), and soil temperature inside greenhouse were measured by sensor package having pyranometer (SP-230SS, Apogee, USA), temperature/RH sensor (STH-CP-01, SYStronics, Republic of Korea), and PT100 type sensor (DK-1202, Dookwang Co. Ltd, Republic of Korea), respectively (Fig. 1). Outdoor solar radiation data was collected by Agricultural Weather Station of PHRI.

The grafted seedling of 'Alchanggul' Korean melon (The Kiban Co. Ltd., Ansung, Republic of Korea) grafted onto 'Hidden Power' (The Kiban Co. Ltd., Ansung, Republic of Korea) was planted on the separate soil bed, which has the size of $2.5 \mathrm{~m}$ wide and $6 \mathrm{~m}$ long, and $0.3 \mathrm{~m}$ high above ground, by $50 \mathrm{~cm}$ apart from right side and by the distance of $40 \mathrm{~cm}$ on $3 \mathrm{March}$. The soil bed was filled with soil made of red clay sand mixed with compost. The chemical properties

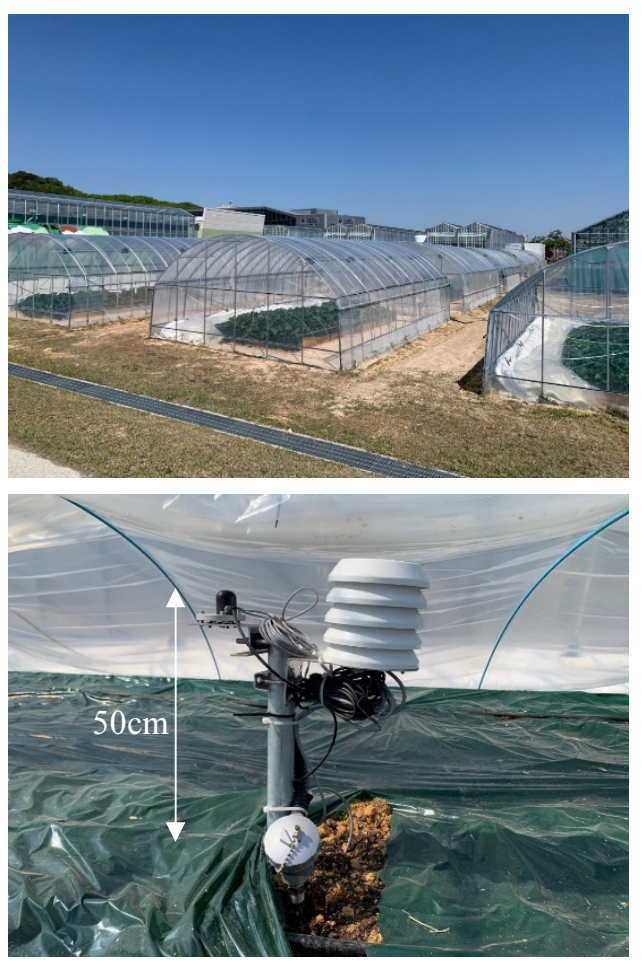

Fig. 1. The greenhouse (left) was structured by iron pipe with $1.3 \mathrm{~m}$ eve height and $2.5 \mathrm{~m}$ ridge height, and covered with $0.15 \mathrm{~mm}$ thick plastic film having the surface area of $40 \mathrm{~m}^{2}$ with $5 \mathrm{~m}$ width and 8 $\mathrm{m}$ length, which was equipped with rolling type side window operated by the temperature sensor located at the center of greenhouse on $1.5 \mathrm{~m}$ height. Microclimate sensors (right) used for this experiment. 
Ventilation at Supra-Optimal Temperature Leading High RH Controls PM, SW, Mite and Inhibits the Flowering of Korean Melon in a Greenhouse

were as follows; $\mathrm{pH} ; 8.0$, electrical conductivity (EC); 1.2 $\mathrm{dS} / \mathrm{m}$, available phosphorus; $337 \mathrm{mg} / \mathrm{kg}, \mathrm{NH}_{4}-\mathrm{N} ; 75 \mathrm{mg} / \mathrm{kg}$, $\mathrm{NO}_{3}-\mathrm{N} ; 187 \mathrm{mg} / \mathrm{kg}$, exchangeable $\mathrm{Ca} ; 3.18 \mathrm{cmol} / \mathrm{kg}$, exchangeable $\mathrm{Mg} 3.64 \mathrm{cmol} / \mathrm{kg}$, exchangeable $\mathrm{K} 4.57 \mathrm{cmol} / \mathrm{kg}$. In order to maintain optimum night temperature polylayered warm keeping fabrics was equipped on man-made plastic tunnel through the closing it before sunset and opening it after sunrise until 19 April. Irrigation and fertigation using liquid fertilizer 'Mulpure 2' (Daeyu co. Republic of Korea) was applied enough by trickle irrigation according to the growth vigor. The other crop managements such as training, topping, fruit setting by bumble bee pollinating, harvesting was done by the standard manual of Korean melon (RDA, 2018). After finishing three times harvesting until 2 June plants was exposed to pests and diseases by stopping the agro-chemical control for this experiment.

Three ventilation treatments by set point value at 45,40 , $35^{\circ} \mathrm{C}$ (control) started on 18 June when powdery mildew, mite and silverleaf whitefly were wide spread on the plants in all the greenhouse and stopped on $13 \mathrm{July}$. Set temperature value was accomplished by opening and closing of role-type side window responding by temperature sensor connected to control panel. When opening, operation time was $10 \mathrm{~s}$ with 30 s delay time. When closing, operation time was $15 \mathrm{~s}$ with 30s delay time.

Plant growth and plant health situation was monitored every day and it was taken by photo at first day, five days and at 11 days after treatments. After 2 weeks of treatment the change of powdery mildew symptom, the population of silverleaf whitefly and two-spotted spider mite, and leaf rolling were investigated by observation revealing as categorical data defined by three levels as follows. 1; decrease, 3; stagnant, 5; increase. The number of male and female flowers bloomed on 15 nodes of the newly grown 5 shoots of plants in every experimental plot was counted at 26 days after treatment.

\section{Experimental design and statistical analysis}

Three treatments with 5 replications were placed by completely random design. The collected data were analyzed by SAS enterprise guide 7.1 version (SAS Institute, Cary, USA). The data of pests and disease occurrence, leaf rolling, and the number of flowers were analyzed by one-way ANOVA and presented with mean value. Significance was determined by Duncan multiple range test at $5 \%(p \leq 0.05)$.

\section{Results and Discussion}

Solar radiation inside greenhouse was recorded for 37 days from 10 June to 16 July including high temperature treatment period of 26 days (Fig. 2). During the treatment period solar radiation inside greenhouse on day was about $80 \%$ of outside solar radiation. Mean solar radiation on day time was $335.8 \mathrm{~W} / \mathrm{m}^{2}$ and the number of sunny days was 21 among 26 days.

During the treatment, mean, maximum and minimum temperature were fluctuated showing differences among treatments responding to outside weather condition (Fig. 3). According to the treatment, mean of day mean temperature were recorded by $30.5,29.4,28.0^{\circ} \mathrm{C}$, and mean of day maximum temperature by $43.9,40.3,37.1^{\circ} \mathrm{C}$, and mean of day minimum temperature by $20.4,20.6,20.4^{\circ} \mathrm{C}$, respectively. Mean of day mean RH were recorded by 82.0, 79.0, 78.6\%, and mean of day maximum RH by $95.4,95.0,96.1$, and mean of day minimum RH by 59.4, 51.2, 50.4\%, respectively. In view of time of day, temperature and $\mathrm{RH}$ differences among treatments were apparent on sunny day in the comparison between sunny day and rainy day (Fig. 4), and temperature and RH differences were continued for about 9 hours although we could not know how many times side window opened and closed. Physically, RH is getting down when



Fig. 2. Changes of solar radiation outside and inside greenhouse for treatment period. Arrow means start and end point of high temperature treatments. Treatment was done for 26 days from 18 June to 13 July. 
Tae Cheol Seo, Jin Hyun Kim, Seung Yu Kim, Myeong Whan Cho, Man Kwon Choi, Hee Ryong Ryu, Hyun Ho Shin, and Choung Keun Lee
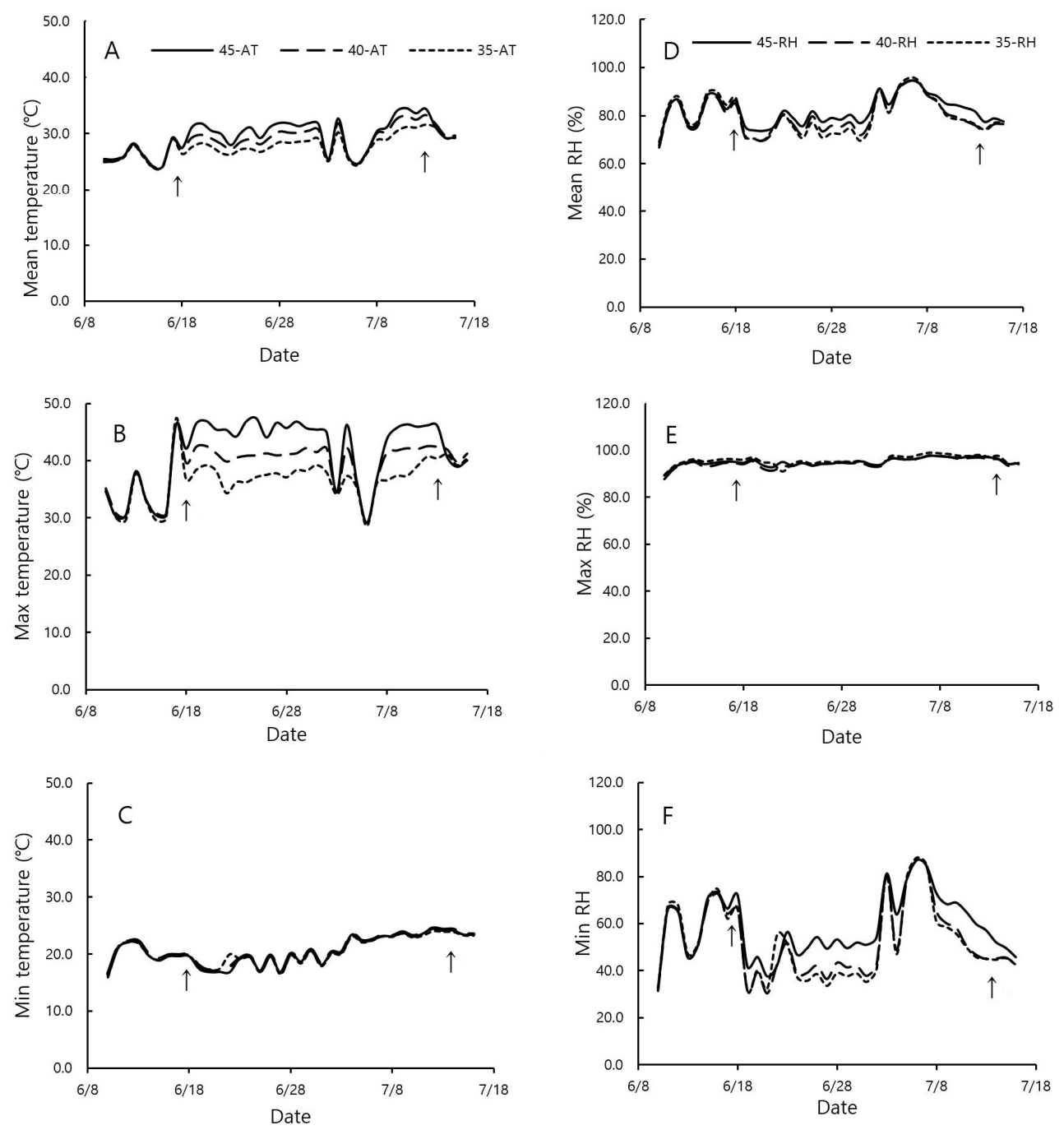

Fig. 3. Changes of air temperature and RH inside greenhouse as affected by temperature treatment, which was accomplished by ventilation through side window operation according to set temperature of $45,40,35^{\circ} \mathrm{C}$ during the treatment. Arrow means starting and end point of treatment. Note: Lowercase A, B, C represent day mean, maximum, minimum temperature and D, E, F represent day mean, maximum, minimum RH, respectively.
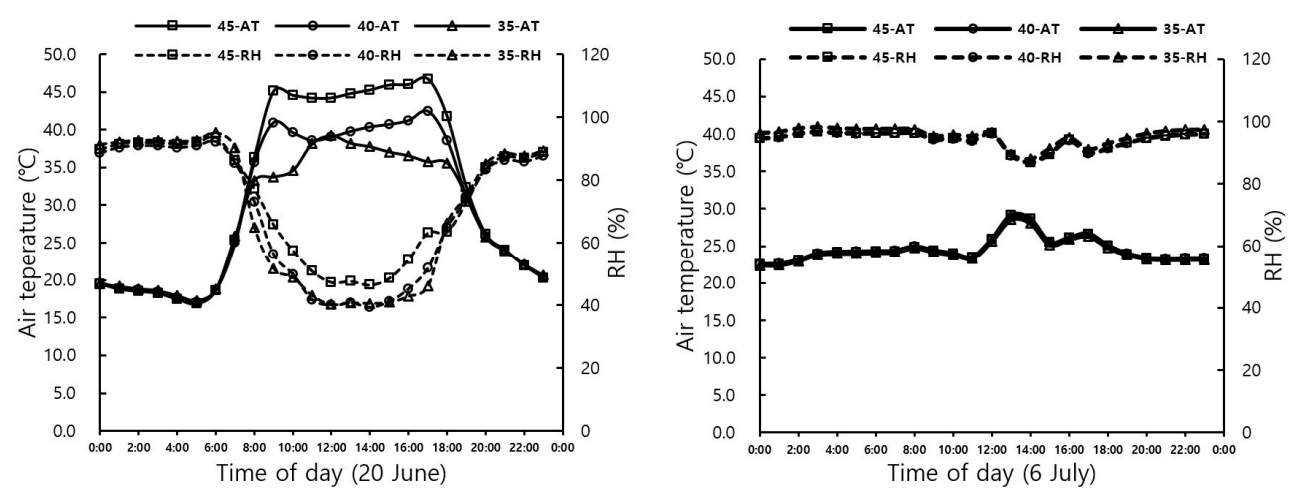

Fig. 4. Comparison of air tempreature and RH inside greenhouse between sunny day (left, on 20 June) and rainy day (right, on 6 July) as affected by temperature treatment, which was accomplished by ventilation through side window operation according to set temperature of $45,40,35^{\circ} \mathrm{C}$ during the treatment. 
temperature is rising up because saturation vapor pressure increases in closed condition. However, RH was higher at high temperature treatment than at lower temperature especially at $45^{\circ} \mathrm{C}$, which was affected by the evapotranspiration of plant and soil (Ge et al., 2021). These results means that hot and humid air stayed longer at $45{ }^{\circ} \mathrm{C}$ than others. Meanwhile $\mathrm{RH}$ gap between $40^{\circ} \mathrm{C}$ and $35^{\circ} \mathrm{C}$ as control was not clear for 6 hours from 10 to 16 o' clock.

For more detail we revealed the differences of temperatures and $\mathrm{RH}$ with the comparison between $45^{\circ} \mathrm{C}$ and $35^{\circ} \mathrm{C}$ (control) and between $40^{\circ} \mathrm{C}$ and $35^{\circ} \mathrm{C}$ during the treatment (Fig. 5). The gap of day maximum temperature between $45^{\circ} \mathrm{C}$ and $35^{\circ} \mathrm{C}$ was in the range of 0.6 to $11.0^{\circ} \mathrm{C}$ showing $6.7^{\circ} \mathrm{C}$ on average during the treatment. The gap of day minimum $\mathrm{RH}$ between $45^{\circ} \mathrm{C}$ and $35^{\circ} \mathrm{C}$ was in the range of -1.3 to $7.2 \%$ showing $3.3 \%$ higher at $45^{\circ} \mathrm{C}$ on average. By these results, we could know that treatment effect was realized at day maximum temperature and at minimum $\mathrm{RH}$.

By everyday monitoring of plant growth and targeting two pests and one disease, we could know that temperature treatment effect starts to show on 5 days later. Therefore, we took photos at 5 and 11 days later and compared. As shown in Fig. 6, the visual growth and damage injured by powdery mildew and two-spotted spider mite was eventually recovered at $45^{\circ} \mathrm{C}$.

In the investigation of pest and disease occurrence after 2 weeks, silverleaf whitefly and two-spotted spider mite were significantly decreased at $45^{\circ} \mathrm{C}$ (Table 1 ). Silverleaf whitefly is known as tropical/subtropical species (Wikipedia, 2021b). Generally, the populations of silverleaf whitefly reach their peak in summer whereas cooler climatic conditions (Luo et al., 2004; Subba et al., 2017). Heat shock can kill whitefly adult when they are exposed suddenly to high temperature above $41{ }^{\circ} \mathrm{C}$ for $1 \mathrm{hr}$ even there is difference in heat tolerance between Bemisia tabaci (Gennadius) biotype B and Trialeurodes vaporariorum (Westwood) (Cui et al., 2008). Meanwhile, the effect of humidity on whitefly populations was controversial. Umar et al. (2003) reported that the correlation of whitefly population abundance and relative humidity was negative for whitefly population on some
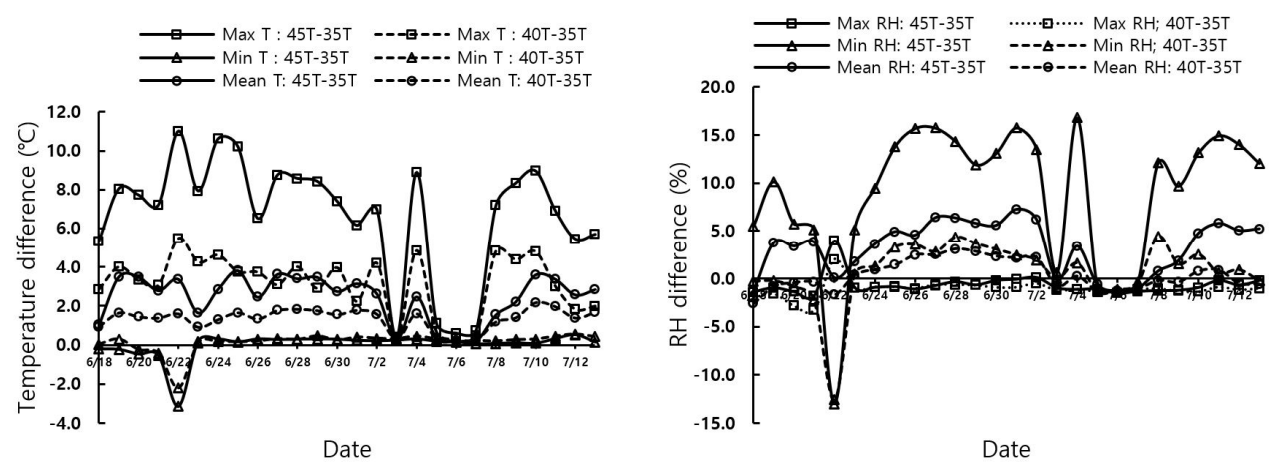

Fig. 5. Changes of differences in day maximum, mean, minimum temperature (left) and RH (right) between treatments as affected by temperature treatment, which was accomplished by ventilation through side window operation according to set temperature of $45,40,35^{\circ} \mathrm{C}$ during the treatment.

Table 1. Changes of pest and disease, and leaf rolling level as affected by temperature treatment, which was accomplished by ventilation through side window operation according to set temperature of $45,40,35^{\circ} \mathrm{C}$ during the treatment period.

\begin{tabular}{|c|c|c|c|c|}
\hline Treatment & Powdery mildew ${ }^{7}$ & Silverleaf whitefly ${ }^{2}$ & Tow-spotted spider mite ${ }^{z}$ & Leaf rolling ${ }^{y}$ \\
\hline $35^{\circ} \mathrm{C}$ & $3.4 \mathrm{a}^{\mathrm{x}}$ & $5.0 \mathrm{a}$ & $3.0 \mathrm{a}$ & $1.40 \mathrm{~b}$ \\
\hline $40^{\circ} \mathrm{C}$ & $2.6 \mathrm{a}$ & $3.8 \mathrm{a}$ & $3.4 \mathrm{a}$ & $3.40 \mathrm{a}$ \\
\hline $45^{\circ} \mathrm{C}$ & $2.2 \mathrm{a}$ & $1.8 \mathrm{~b}$ & $1.0 \mathrm{~b}$ & $3.80 \mathrm{a}$ \\
\hline
\end{tabular}

${ }^{\mathrm{z}}$ Pest and disease occurrence were investigated by categorical data as follows. 1; decrease, 2: stagnant, 5; Increase.

${ }^{y}$ Leaf rolling was investigated by categorical data as follows. 1: no symptom, 3; moderate, 5: severe.

${ }^{\mathrm{x}}$ Mean separation within columns by Duncan's multiple range test, $p \leq 0.05$. 
Tae Cheol Seo, Jin Hyun Kim, Seung Yu Kim, Myeong Whan Cho, Man Kwon Choi, Hee Ryong Ryu, Hyun Ho Shin, and Choung Keun Lee

varieties of cotton. But, Jha and Kumar (2017) reported that population of whitefly with morning and evening RH had a positive relation in tomato. Recently, Thinnabut et al. (2020) reported that only dew point had a significant positive regression with whitefly populations in tomato grown in greenhouse reviewing that these differential results may depend on other conditions such as plant varieties, natural enemies, and cultural management. In our study, the decrease of silverleaf whitefly was thought to be induced by combination effect of high temperature and high $\mathrm{RH}$ at $45^{\circ} \mathrm{C}$ ventilation treatment for more than 2 weeks. Nevertheless, this treatment could not control this insect completely because they are survived in the greenhouse. Another concern is that this insect may adapt to high temperature like adapting to agro-chemicals (Luo et al., 2010).

In two-spotted spider mite, we could find out the high temperature with high humidity effect clearly after 14 days (Table 1). we could see no more dispersion of mite damage on plant leaves at $45^{\circ} \mathrm{C}$ treatment. Temperature and host plants affect the development and reproduction the spider mites (Praslička and Huszá, 2004; Zou et al., 2018). Farazmand (2020) reported recently in modelling study using cucumber leaves that the egg-to-adult development time of this insect decreased significantly with increasing temperature in the range of 15 to $32.5^{\circ} \mathrm{C}$, except at $35^{\circ} \mathrm{C}$ and several models estimated the value of $\mathrm{T}_{\max }$ to be in the range from $32^{\circ} \mathrm{C}$ to $41^{\circ} \mathrm{C}$. In relation to $\mathrm{RH}$, spider mites are more easily controlled in greenhouse when high $\mathrm{RH}$ is maintained (Bouderaux, 1958). Oviposition was accelerated under low humidity through morphological responses of host cucumber leaves (Shibuya et al., 2016). Renkema et al. (2020) reported recently that the steam at $48^{\circ} \mathrm{C}$ could kill adult females and eggs on strawberry leaf discs within 2.7 and $1.9 \mathrm{hr}$, respectively.

Powdery mildew was not significantly different among treatment although showing decreasing pattern with the increase of temperature in this experiment. It is known that optimum temperature of powdery mildew occurrence in Korean melon is in the range of 15 to $28^{\circ} \mathrm{C}$ and was inhibited above $32^{\circ} \mathrm{C}$ (NCPMS, 2020). In addition, this disease occurs when the value of diurnal change of temperature and $\mathrm{RH}$ is high on spring season. Ventilation is a useful method to control microclimate especially air temperature and $\mathrm{RH}$ in the greenhouse whether it is forced or not. Generally, it can be inferred that indoor $\mathrm{RH}$ increases by plant transpiration in a closed condition. Roof and side ventilation were more effective than simple side ventilation to inhibit the occurrence
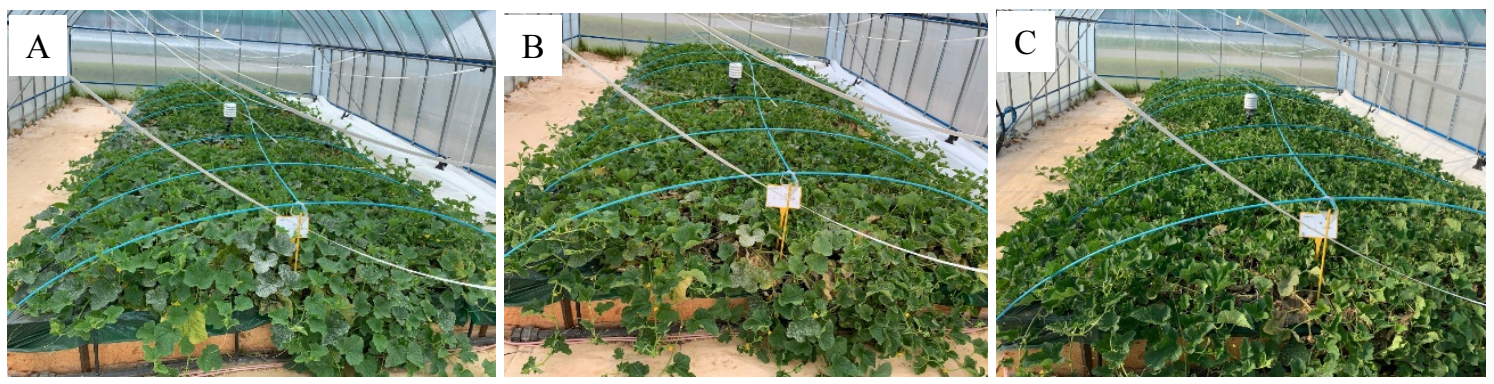

Fig. 6. Visual change of Korean melon at $45^{\circ} \mathrm{C}$ treatment. A; before, B; 5 days later, $\mathrm{C} ; 11$ days later.

Table 2. Flowering numbers observed at a newly grown shoot after 26 days as affected by temperature treatment, which was accomplished by ventilation through side window operation according to set temperature of $45,40,35^{\circ} \mathrm{C}$ during the treatment period.

\begin{tabular}{lccc}
\hline \hline Treatment & No. of counted node & $\begin{array}{c}\text { Female flower } \\
(/ \text { shoot })\end{array}$ & $\begin{array}{c}\text { Male flower } \\
(/ \text { shoot })\end{array}$ \\
\hline $35^{\circ} \mathrm{C}$ & 15 & $3.12 \mathrm{a}^{\mathrm{z}}$ & $7.28 \mathrm{a}$ \\
$40^{\circ} \mathrm{C}$ & 15 & $2.48 \mathrm{a}$ & $5.56 \mathrm{~b}$ \\
$45^{\circ} \mathrm{C}$ & 15 & $0.00 \mathrm{~b}$ & $1.12 \mathrm{c}$ \\
\hline
\end{tabular}

${ }^{\mathrm{z}}$ Mean separation within columns by Duncan's multiple range test, $p \leq 0.05$. 
rate of this disease in Korean melon (Yeo et al., 2015). The reason why the effect of high temperature on powdery mildew was not significant was that this disease was already enduring the powdery mildew even at control condition showing higher day temperature above $32^{\circ} \mathrm{C}$ on sunny day (Fig. 3).

Leaf rolling level was higher at $40^{\circ} \mathrm{C}$ and $45^{\circ} \mathrm{C}$ (Table 1). This means that high temperature gave this plant heat stress (Kadioglu et al., 2012). But the extent was not severe showing no concern about survival. We can see the rolled leaves in farming field during from late spring to summer season. The Korean melon is known as a cool sub-temperate crop, growing best with day temperatures between 24 and $28^{\circ} \mathrm{C}$ and night temperatures between 16 and $24^{\circ} \mathrm{C}$ (Wikipedia, 2021a). The cultivated Korean melon in Korea, however, is tolerant to high temperature by $40^{\circ} \mathrm{C}$ for short period (RDA, 2018).

In the investigation of the number of flowers, female flowers did not develop at $45^{\circ} \mathrm{C}$ showing decreasing from 3.1 to 2.5 between 35 and $40^{\circ} \mathrm{C}$, and male flower decreased from 7.3 to 1.1 with the increase of temperature (Table 2). Total number of flowers were also decreased. It is known that the recently cultivated Korean melon is monoecious and fruiting well on the son vine and grandson vine and has a different flowering habit according to genetic characteristics and environmental condition, and that female flower changes to male flower more often in high temperature with long photoperiod condition (RDA, 2018). High temperature and photoperiod are known to more decisive environmental factors to determine sex expression than any other environmental factors (Lai et al., 2018). We could observe these changes in this study clearly. In another point of view, the decrease of flowering means that plant can afford to recover vegetative growth by reducing fruit setting that induce sink load when the plant vigor is weak (Nerson, 2004; Smith et al., 2018). Therefore, ventilation at $45^{\circ} \mathrm{C}$ using side window operation could be an applicable practice to manage plant vigor and control above mentioned disease and pests occurred concurrently at Korean melon farm field during the summer season.

Nevertheless, these ventilation control at high temperature should be carefully applied in Korean melon cultivation greenhouse because strong solar radiation following with extremely high temperature increases evapotranspiration induced by the increased vapor pressure deficit. Thus, enough water supply should be essentially needed to adapt to water stress and partial root-zone drying (Lamaoui et al., 2018). In addition, further studies are needed to quantify the final yield and quality of Korean melon after recovery of vegetative growth since oxidative damage is accelerated by exposal to drought and heat stress (Fahad et al., 2017).

\section{Acknowledgements}

This study was made possible by the support of the Rural Development Administration Research Project (PJ01532701).

\section{Literature Cited}

Bouderaux H.B. 1958, The effect of relative humidity on egg-laying, hatching, and survival in various spider mites. J Insect Physiol 2:65-72.

Choi D.W. 2013, Satisfaction and management performance of Korean melon powdery mildew control technology by environmental control. Rural Development Administration, Farming technology information. http://www.nongsaro.go.kr. Accessed 29. Oct. 2021.

Cui X., F. Wan, M. Xie, and T. Liu 2008, Effect of heat shock on survival and reproduction of two whitefly species, Trialeurodes vaporariorum and Bemisia tabaci biotype B. J Insect Sci 8:1-10.

Fahad S., A.A. Bajwa, U. Nazir, S.A. Anjum, A. Farooq, A. Zohalb, S. Sadia, W. Nasim, S. Adkins, S. Saud, M.Z. Ihsan, H. Alharby, C. Wu, D. Wang, and J. Huang 2017, Crop production under drought and heat stress: Plant responses and management options. Front Plant Sci 8:1147. doi:10.33 89/fpls.2017.01147

Farazmand A. 2020, Effect of the temperature on development of Tetranychus urticae (Acari: Tetranychidae) feeding on cucumber leaves. Int J Acarol 46:381-386. doi:10.1080/016 47954.2020.1805001

Ge J., L. Zhao, X. Gong, Z. Lai, S. Traore, Y. Li, H. Long, and L. Zhang 2021, Combined effects of ventilation and irrigation on temperature, humidity, tomato yield, and quality in the greenhouse. HortScience 56:1080-1088. doi:10.21273/HO RTSCI16044-21

Jha S.K., and M. Kumar 2017, Effect of weather parameters on incidence of whitefly, Bemisia tabaci (Gennadius) on tomato. J. Entomo Zoo Studies 5:304-306.

Kadioglu A., R. Terzi, N. Saruhan, and A. Saglam 2012, Current advances in the investigation of leaf rolling caused by biotic 
Tae Cheol Seo, Jin Hyun Kim, Seung Yu Kim, Myeong Whan Cho, Man Kwon Choi, Hee Ryong Ryu, Hyun Ho Shin, and Choung Keun Lee

and abiotic stress factors. Plant Sci 182:42-48.

Lai Y.S., D. Shen, W. Zhang, X. Zhang, Y. Qiu, H. Wang, X. Dou, S. Li, Y. Wu, J. Song, G. Ji, and X. Li 2018, Temperature and photoperiod changes affect cucumber sex espression by different epigenetic regulations. BMC Plant Bio 18:268. doi:10.1186/s12870-018-1490-3

Lamaoui M., A. Chakhchar, Y.E. Kharrassi, S. Wahbi, and C.E. Modatar 2018, Morphological, physiological, and biochemical responses to water stress in melon (Cucumis melo) subjected to regulated deficit irrigation (RDI) and partial rootzone drying (PRD). J Crop Sci Biotech 21:407-416. doi:10.1007/s 12892 $-018-0122-0$

Leigh A., S. Sevanto, J.D. Close, and A.B. Nicotra 2017, The influence of leaf size and shape on leaf thermal dynamics does theory hold up under natural conditions?. Plant Cell Environ 40:237-248. doi:10.1111/pce.12857

Luo C, S.O. Wang, W.Q. Cui, and Z.L. Zhang 2004, The population dynamics of whiteflies and their natural enemy in Beijing suburb. Modern Entomology Research, Agricultural Science Press Beijing, China, pp 465-468.

Luo C., C.M. Jones, G. Devine, F. Zhang, I. Denholm, and K. Gorman 2010, Insecticide resistance in Bemisia tabaci biotype Q (Hemiptera: Aleyrodidae) from China. Crop Prot 29:429-434. doi:10.1016/j.cropro.2009.10.001

McClung C.R., P. Lou, V. Hermand, and J.A. Kim 2016, The importance of ambient temperature to growth and the induction of flowering. Front Plant Sci 7:1266. doi:10.3389/fpls.2016. 01266

National Crop Pest Management System (NCPMS) 2020, https: //ncpms.rda.go.kr/ncpms/Main.np.

Nerson H. 2004, Source-sink relationships and their effects on fruit growth and quality in casaba melon (Cucumis melo L. var. Inodorous). Fruit Veg Cereal Sci Biotech 3:44-47.

Park Y.J., H.J. Lee, K.E. GIL, J.Y. Kim, J.H Lee, H. Lee, H.T. Cho, L.D. Vu. L. De Smet, and C.M Park 2019, Developmental programming of thermonastic leaf movement. Plant Physiol 180:1185-1197. doi:10.1104/pp.19.00139

Praslička J., and J. Huszá 2004, Influence of temperature and host plants on the development and fecundity of the spider mite. Plant Protect Sci 40:141-144. doi:10.17221/465-PPS

Renkema J., F. Dubon, N. Peres, and B. Evans 2020, Twospotted spider mites (Tetrancychus urticae) on strawberry (Fragaria $\times$ ananassa) transplants, and the potential to eliminate them with steam treatment. International Journal of Fruit Science 20:978-991. doi:10.1080/15538362.2020.1755769
Rural Development Administration (RDA) 2018, Korean melon cultivation. The guide book of agricultural technology 105 . RDA, Korea, pp 25-28.

Shibuya T., K. Itagaki, S. Ueyama, N. Hirai, and R. Endo 2016, Atmospheric humidity influences oviposition rate of Tetranychus urticae (Acari: Tetranychidae) through morphological responses of host Cucumis sativus leaves. J Econ Entomol 109:255-258. doi:10.1093/jee/tov312

Smith M.R., I.M. Rao, and A. Merchant 2018, Source-sink relationships in crop plants and their influence on yield development and nutritional quality. Front Plant Sci 9:1889. doi:10.3389/FPLS.2018.01889

Subba B., S. Pal, T. Mandal, and S.K. Ghosh 2017, Population dynamics of whitefly (Bemisia tabaci Genn.) infesting tomato (Lycopersicon esculentus L.) their sustainable management using bio pesticides. J Entomol Zool Stud 5:879-883.

Thinnabut K., D. Thongpak, C. Choosai, and U. Tangkawanit 2020, Influence of meteorological parameters on population of whitefly, Bemisia tabaci on greenhouse-grown tomatoes. Int J Enviro Rural Develop 11:40-44.

Umar M.S., M.J. Arif, M.A. Murtaza, M.D. Gogi, and M. Salman 2003. Effect of abiotic factors on the population fluctuation of whitefly, Bemisia tabaci (Gen) in nectaried and nectariless genotype of cotton. Int J Agri Biol 5:362-363.

Vu L.D., X. Xu, K. Gevaert, and I.D. Smet 2020, Developmental plasticity at high temperature. Plant Physio 181:399-411. doi:10.1114/pp.19.00652

Wikipedia 2021a, Oriental melon. https://en.wikipedia.org/wi ki/Oriental_melon\#cite_note-Kato-5.

Wikipedia 2021b, Silverleaf whitefly. https://en.wikipedia.org /wiki/Silverleaf whitefly.

Yeo K.H., I.H. Yu, H.C. Rhee, G.L. Choi, S.C. Lee, and J.S. Lee 2015, Effects of ventilation systems and set point temperature of single-span plastic greenhouse on disease incidence, fruit quality and yield of Oriental melon (Cucumis melo L.). Korean J Agric Sci 42:325-333. (in Korean) doi:10.7744/CNUJAS. 2015.42.4.325

Yeon I.K., C.K. Shim, M.J. Kim, J.M. Park, W.K. Jung, H.W. Do, and S.H. Park 2020, Research status of environmental friendly management for Korean melon powdery mildew. Korean J Pestic Sci 24:136-147. doi:10.7585/kjps.2020.24.2.136

Zou Z., J. Xi, G. Liu, S. Song, T. Xin, and B. Xia 2018, Effect of temperature on development and reproduction of the carmine spider mite, Tetranychus cinnabariuns (Acari; tetranychidae), fed on cassava leaves. Exp Appl Acarol 74:383-394. doi:10.1007/s10493-018-0241-3 


\title{
참외 시설 재배 시 고온에서의 환기 처리에 의한 상대습도 상승과 흰가루병, 담배가루이, 응애 방제 및 개화 억제
}

\author{
서태철 ${ }^{*} \cdot$ 김진현 $^{2} \cdot$ 김승유 $^{1} \cdot$ 조명환 $^{2} \cdot$ 최만권 $^{2} \cdot$ 류희룡 $^{4} \cdot$ 신현호 $^{3} \cdot$ 이충근 $^{1}$
}

${ }^{1}$ 농촌진흥청 국립원예특작과학원 시설원예연구소 농업연구관, ${ }^{2}$ 농촌진흥청 국립원예특작과학원 시설원예연구소 농업연구사,

농촌진흥청 국립원예특작과학원 시설원예연구소 전문연구원, ${ }^{4}$ 농촌진흥청 연구정책국 연구성과관리과 농업연구사

적 요. 본 연구는 참외 재배 지에서 흰가루병, 담배가루이 및 두점박이응애가 동시에 발생하였을 때 $45,40,35^{\circ} \mathrm{C}$ (대조구)의 온도에서 측창으로 환기 처리 시, 온실 내 온·습도의 변화, 병충해 발생과 잎말림, 그리고 개화조절에 미 치는 효과를 검토하였다. 3 월 3일 ‘히든파워' 대목에 접붙여진 '알찬꿀' 참외를 $40 \mathrm{~cm}$ 간격으로 격리상에 심었고, 위 에 언급한 병해충이 모든 처리구에서 발생한 6 월 18 일부터 7월 13 일까지 처리하였다. 온실의 온도는 맑은 날에는 설정 온도 지점까지 증가되었고, $45^{\circ} \mathrm{C}$ 환기 처리에서 고온 고습이 약 9 시간 동안 유지되었다. 주간 최고 기온과 최 저 상대습도 차이는 $45^{\circ} \mathrm{C}$ 환기 처리에서 가장 높았다. 환기 처리 11 일 후에는 흰가루병과 두점박이응애 피해가 $45^{\circ} \mathrm{C}$ 환기 처리에서 거의 회복되었지만 $40^{\circ} \mathrm{C}$ 와 $35^{\circ} \mathrm{C}$ 에서는 그렇지 않았다. 처리 14 일 후, 담배가루이와 두점박이 응애 밀도는 $45^{\circ} \mathrm{C}$ 에서 유의하게 감소하였으나 흰가루병 증상은 유의하게 감소하지는 않았다. 잎말림은 고온에서 유발되었으나 $45^{\circ} \mathrm{C}$ 에서도 심하지 않았다. 처리 26 일 후, 새로 나온 줄기의 15 마디의 개화수를 조사한 결과, $45^{\circ} \mathrm{C}$ 에 서 암꽃이 전혀 나오지 않았고 수꽃은 1.2 개로 나타났다. 이상의 결과는, 고온기에 $45^{\circ} \mathrm{C}$ 의 고온에서 $2-3$ 주간 환기 처리는 온실 내부의 고온 고습을 유도하여 흰가루병, 담배가루이, 두점박이응애를 통제하고, 개화를 억제하여 참외 의 영양 생장을 회복할 수 있는 방법으로 사료되었다.

추가 주제어: 담배가루이, 잎말림, 미기상, 흰가루병, 두점박이응애 